\title{
ANALYSIS OF THE ATTITUDE OF PHARMACY SPECIALISTS TOWARDS THE CURRENT SOCIAL PROTECTION SYSTEM AND DIRECTIONS FOR ITS REFORMATION
}

\author{
M.V.Zarichkova \\ National University of Pharmacy \\ Key words: social protection of pharmacy specialists; social services; pharmaceutical industry; \\ authorised person responsible for social issues; labour protection; ADPQ_(SPPhS) software \\ application
}

The social status of pharmacy specialists (PhS) of the wholesale and retail branch of the pharmaceutical industry of Ukraine and their attitude towards the current social protection (SP) system have been analysed. The possibilities of PhS to gain social protection at their workplace, participate in social programmes and offers to reform the current SP system have been studied. It has been found that civil and self-regulating organisations in the system of social protection of pharmacy specialists (SPPhS) are of primary importance. This will enable to improve relations between participants of SPPhS and affect efficiently the solution of disputes between a PhS and an employer. For this purpose it has been offered to assign an authorised person who is responsible for social issues in the labour collective of pharmaceutical institutions of all types of ownership. The software application ADPQ_(SPPhS) (Automatic data processing questionnaires (the attitude to the current social protection for pharmacy specialists (SPPhS)) has been developed for the first time with the purpose of processing the results of SPPhS research of the wholesale and retail branch of the pharmaceutical industry of Ukraine.

The pharmaceutical industry is important and it is one of the strategic sectors of the economy of Ukraine because it is responsible for health of the nation and provision of the population with medicines and medical supplies. Taking into account the fact that work of pharmacy specialists $(\mathrm{PhS})$ is associated with emotional tension during all working hours (a human factor), and that they deal with different categories of medicines (narcotic, toxic, potent, radioactive, the plant medicinal raw material, etc.), which can cause a threat to health (occupational diseases), employees of the pharmaceutical industry need special protection by the state and employers, especially it concerns social protection (SP). Today social protection of pharmacy specialists (SPPh) is implemented in the system of SP of the population, but unfortunately, there is no separate state regulation of SPPhS. This caused conducting a sociological study of $\mathrm{PhS}$ of the wholesale and retail branch of the pharmaceutical industry of Ukraine to determine their social status and attitude towards the current system of SP $[1-4,9,10]$.

Our study was conducted in two phases; thereby contributed to obtaining more detailed information from $\mathrm{PhS}$ - potential consumers of social services at wholesale and retail enterprises of the pharmaceutical industry of Ukraine.

The first phase was devoted to determination of the social status of the $\mathrm{PhS}$ interviewed and their positioning in the SP system of Ukraine. The respondents were $\mathrm{PhS}$ of the wholesale and retail branch of the pharmaceutical industry of Ukraine.

The second phase was directed to identification of the attitude of the PhS interviewed towards the current
SP system, their ability to be assisted at their workplace, participation in social programmes and identification of the offers concerning the reformation of the current system of SPPhS.

\section{Materials and Methods}

The study was conducted based on the social survey using questionnaires for $\mathrm{PhS}$ of the wholesale and retail branch of the pharmaceutical industry of Ukraine in Kyiv, Dnipropetrovsk, Donetsk, Luhansk, Poltava, Sumy and Kharkiv regions. The total amount of the study sample constituted 1000 respondents. The software application ADPQ (SPPhS) (Automatic data processing questionnaires (the attitude to the current social protection for pharmacy specialists (SPPhS)) was used for the first time to process the results obtained. It has been developed at the Department of Management and Economics of Pharmacy of the Institute of Pharmacy Professionals Qualification Improvement at the National University of Pharmacy. This software processes and analyses the data obtained, allowing access from specific facts to general conclusions and, in some cases, making a forecast of the study process development $[5-9,11]$.

\section{Results and Discussion}

Social and demographic characteristic of the PhS participated in the study. We interviewed $\mathrm{PhS}$, who occupy different posts: Head of a pharmacy; Deputy Head of a pharmacy; Head of a Department; Deputy Head of a Department; Head of a warehouse; Head of a pharmacy outlet; Director; Senior Pharmaceutist; Pharmaceutist; Pharmacist; Office Worker.

The PhS participated in our study work at wholesale and retail pharmacies of different forms of ownership: 


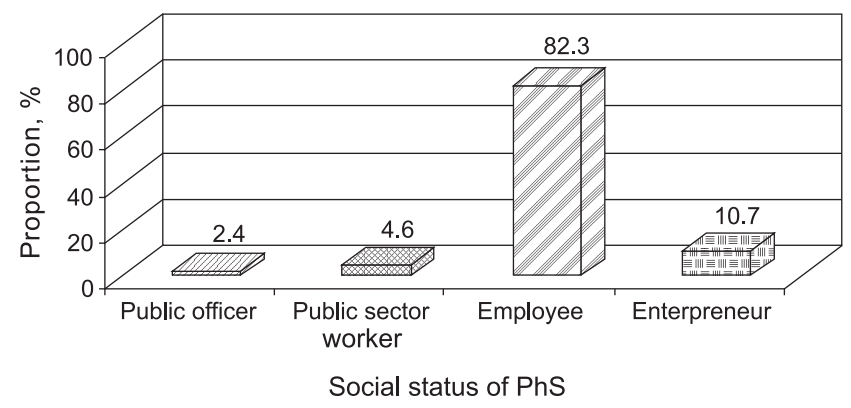

Fig. 1. Division of $\mathrm{PhS}$ according to their social status.

state, municipal and private. In particular, they are the staff of such pharmaceutical institutions as pharmacy, pharmacy outlet, pharmacy warehouse, office of a pharmaceutical company.

According to their social status $\mathrm{PhS}$ were divided into four categories shown in the graph (Fig. 1).

As shown in Fig. 1, 2.4\% of PhS are public officers, $4.6 \%$ of $\mathrm{PhS}$ are public sector workers, $82.3 \%$ of $\mathrm{PhS}$ are employees and $10.7 \%$ of $\mathrm{PhS}$ are entrepreneurs. Most $\mathrm{PhS}$ are employees who depend on the company where they work financially and socially; and according to our study, not all of them feel socially protected.

Among the respondents, most PhS use SP in the SP system of the population and they have not experienced the participation in SPPhS, they use mostly SP programmes shown in Fig. 2.

As shown in Fig. 2, according to the percentage most $\mathrm{PhS}$ of our social survey participate in such state programmes of social protection as: a labour veteran $-6.1 \%$; a disabled person of group I; a disabled person of group II; a disabled person of group III - 2.1\%; a war veteran; a child of war; a combatant; a disabled person of the Great Patriotic War $-1.5 \%$.

According to our data, the priority of public social programmes is based on rather important parameters, which characterize their quality and credibility level to the aimed social impact. With regard to other existing social programmes, it has been found that the $\mathrm{PhS}$ interviewed are not experienced in the use of them and are unable to obtain the desired SP by the employer [10].
Our studies have shown that $\mathrm{PhS}$ - entrepreneurs find ways of protection by themselves and they do not wait for any assistance from the state and employers, so that they do not use the existing state programmes of SP.

Generally, only $13 \%$ of the PhS interviewed have applied for social support at workplace and received some of it. Other $87 \%$ have not had such experience, chance and desire, and they have not got social support at the workplace. The abovementioned fact indicates the absence of effective cooperation between an employer and a $\mathrm{PhS}$ concerning social stability and prosperity. This may lead to conflicts between a $\mathrm{PhS}$ and an employer, and as a result, may lead to conflicts between them and the executive authorities.

Complexity and variety of unsolved social problems, expansion of the range of demands in social services among $\mathrm{PhS}$ result in the need to implement a lot of pressing problems, namely to search scientific reasonable options and models of SPPhS provision, to determine the place and part of social security in it, to develop forms, methods and means of protection against threats and emergencies of the social nature, as well as to train the qualified personnel, who are competent to solve the abovementioned problems.

We recommend assigning an authorized person who is responsible for social issues (APSI) at the labour collective of pharmaceutical institutions of all types of ownership as one of the ways to settle the issues mentioned. We also suggest to determine qualifying requirements towards the APSI's activity and to develop duty regulations. It is also advisable to enhance the role of civil and self-regulated organisations in the SPPhS system. Assigning an APSI will enhance the role of the labour collective in the SPPhS system and will make the SP system more effective and focused on the current needs for social services of $\mathrm{PhS}$ in Ukraine [2, 3, 4].

It has been found that most of the $\mathrm{PhS}$ interviewed $(52.3 \%)$ do not participate in the programmes of the social security insurance and obtaining of social benefits (Fig. 3).

According to the ranking conducted, retirement pensioners are at the top $-15.5 \%$. According to the degree of demand, there are social insurance programmes, in-

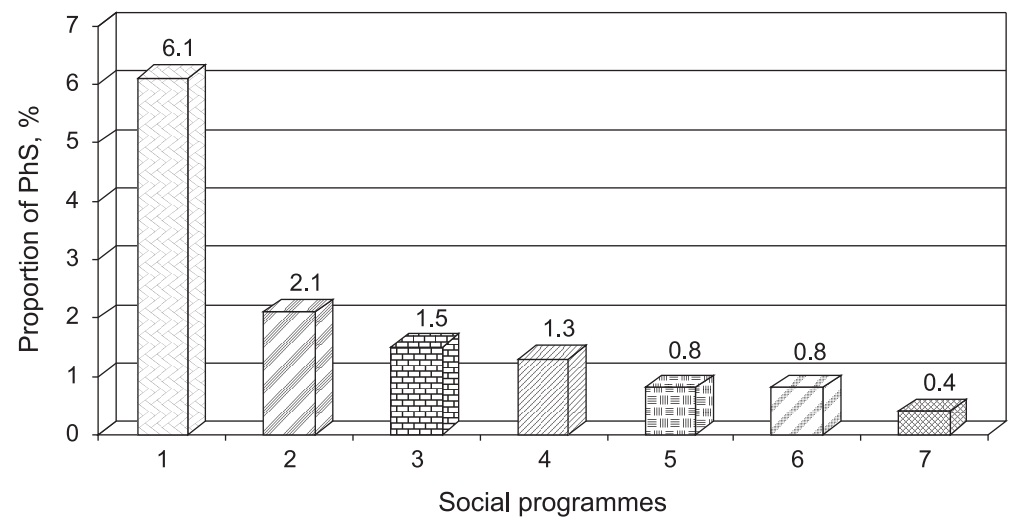

Fig. 2. Social protection programmes, in which the PhS under study participate Symbols: 1 - labour veteran; 2 - disabled person of group I; disabled person of group II; disabled person of group III; 3 - war veteran; child of war; combatant; disabled person of the Great Patriotic War; 4 - liquidators of the Chernobyl disaster; person affected by the Chernobyl disaster; 5 - single mother; 6 - other categories; 7 - large family. 


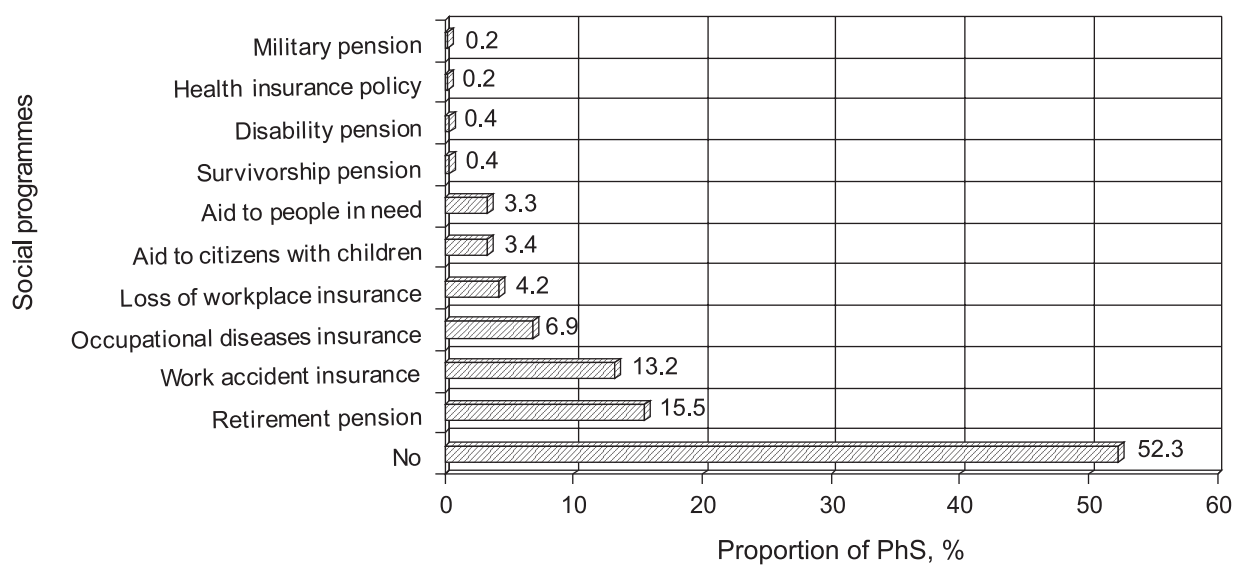

Fig. 3. Social benefits received by the PhS interviewed.

cluding the work accident insurance $-13.2 \%$, the occupational diseases insurance $-6.9 \%$, the loss of workplace insurance $-4.2 \%$. Finally, the lowest percentage accounts for $\mathrm{PhS}$ participating in such social programmes as aid to citizens with children $-3.4 \%$; aid to people in need $-3.3 \%$; survivorship pension $-0.4 \%$; disability pension $-0.4 \%$; military pension $-0.2 \%$; health insurance policy $-0.2 \%$.

During the second phase we have found out the attitude of PhS towards the SP system at workplaces and the opportunities to use SP. It is known that there are many structures that must provide the population with SP in Ukraine. However, the legislation does not provide certain $\mathrm{SP}$ for $\mathrm{PhS}$ taking into account the specificity of their activities. Therefore, reformation of the SP system of Ukraine and separation of SPPhS into an independent branch within the general system of SP of the population require establishment of the executive body. For these reasons the credibility level of $\mathrm{PhS}$ and effectiveness of SPPhS providing among the existing institutions concerning SP have been found during the survey. The study results are presented in Fig. 4.

As shown in Fig. 4, the majority of the PhS interviewed $-45 \%$ express confidence in the Ministry of Labour and Social Policy (in cooperation with the Employment Fund). This authority is responsible for the current state of SPPhS within the system SP of the population. $25 \%$ of the $\mathrm{PhS}$ interviewed would like an employer to be responsible for SPPhS. According to the opinion of $19 \%$ of the respondents, the sector trade unions should be responsible for $\mathrm{PhS}$ and provide them with SP. Private insurance funds receive 5\% of the PhS' confidence, and it is clear taking into account the current state of the economy of Ukraine.

Credibility of the SPPhS performance by the councils of labour groups is expressed only by $3 \%$ of the respondents. It is explained by the lack of experience of such work among labour collectives in the pharmaceutical industry.

Based on these facts we can conclude that there is a need to enhance the role of civil and self-regulated organisations in the SPPhS system. It will make relations between the parties of SPPhS efficient, and solve all issues on SP between a PhS, an employer and the executive authority in the optimal way.

During the study we simulated the following situation in the experiment: respondents were asked to describe the components of the concept "social protection of pharmacy specialists". It has been found that the system of SP of the population should include such concept as "social protection of pharmacy specialists". It is also necessary to develop the system of social services and SPPhS provision by employers within the pharmaceutical industry of Ukraine. In general, it has been determined that a large number of concepts listed in Fig. 5 is important for PhS while defining the SPPhS [4].

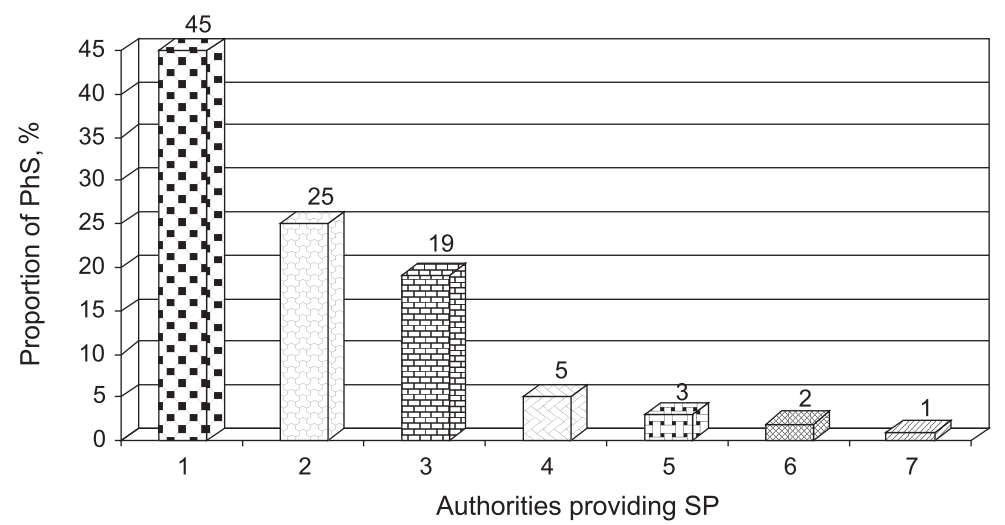

Fig. 4. Credibility in the authorities providing SPPhS Symbols: 1 - the Ministry of Labour and Social Policy in cooperation with the Employment Fund; 2 - employer; 3 - sector trade unions; 4 - private insurance funds; 5 - the council of the labour collective; 6 - a new structure; 7 - Verkhovna Rada (Parliament), the Ministry of Public Health. 


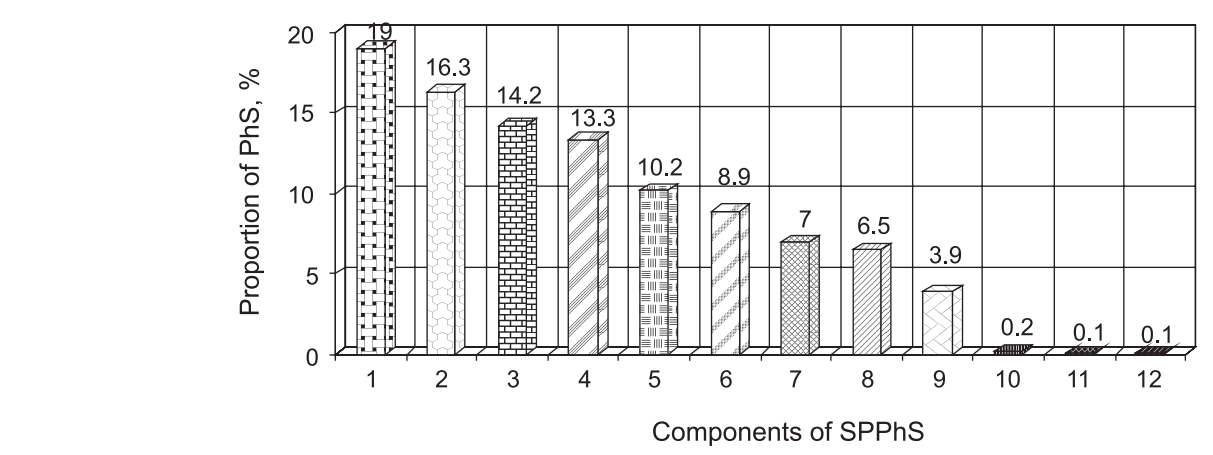

Fig. 5. The PhS attitude towards the components of the definition of SPPhS. Symbols: 1 - social insurance; 2 - income provision in case of disability or loss of workplace; 3 - treatment and prevention of occupational diseases; 4 - protection of social rights and minimum guarantees;

5 - assistance in education and advanced training of pharmacy specialists; 6 - social support and assistance; 7 - protection against professional burnout; 8 - social support of disabled citizens; 9 - healthy lifestyle promotion; 10 - wage; 11 - improvement in health and spa facilities; 12 - behavioural orientation "do not leave people to the mercy of fate".

As shown in Fig. 5, the majority of the PhS interviewed (19\%) would like to have social security insurance for their protection. Concern for their status when losing the workplace is the following, so $16.3 \%$ of the $\mathrm{PhS}$ interviewed want to be insured and their income is secured in case of disability or loss of workplace. This concern is caused by economic instability in Ukraine and by fear to be unemployed and to lose initial assets.

The need in treatment and prevention of occupational diseases takes the third place among the $\mathrm{PhS}$ interviewed (14.2\%). There are almost no measures on labour protection (LP) at workplaces today. The importance of preventive measures on LP is widely recognized in various sectors of the economy; and as for the pharmaceutical industry, this issue is considered in the manufacturing sector mainly, but a lot of pressing issues on this case are still unresolved in pharmacies and their structural subdivisions.

At the same time LP is one of the responsibilities of the state and the society. Not only specialists that are responsible for LP issues at the enterprise level, but also numerous ordinary and new participants are involved into LP. The health of $\mathrm{PhS}$ and performance indicators are based not only on production factors, but also on non-production ones. Therefore, this problem-solving approach should be more integrated and holistic with involvement of various parties who have different experience and skills. At the pharmacy level one of the main obstacles to improve LP is the opinion that the expenses for the prevention of LP are unprofitable and they decrease the competitiveness of a pharmacy $[2,3]$.

According to the opinion of the $\mathrm{PhS}$ interviewed the following components are also important: $13.3 \%$ - protection of social rights and minimum guarantees; $10.2 \%$ - assistance in education and advanced training of pharmacy specialists; $8.9 \%$ - social support and assistance; $7 \%$ - protection against professional burnout; $6.5 \%$ social support of disabled citizens, etc.
The studies conducted confirm the need to reform the current SP system and to separate SPPhS into an independent branch.

\section{CONCLUSIONS}

1. The social status of $\mathrm{PhS}$ and their attitude towards the current SP system at the workplace have been studied. It has been found out that the current legislation regulating the implementation of SP, should be reconsidered, improved and harmonized with the EU policy documents. Taking into account the specificity of the pharmaceutical industry it is necessary to create an independent system of SPPhS. This requires updating of the SPPhS legislative framework, which must be based on the European principles and take into account the needs of $\mathrm{PhS}$ and employers.

2. We have created a ADPQ (SPPhS) computer programme. It is efficient when conducting sociological surveys with a great number of respondents and questions. It allows taking into account most indicators of the qualitative nature as there is a human factor when questioning, so it enables obtaining more reliable results of the statistical data processing. It allows interpreting the data obtained scientifically and using them in the further studies.

3. There is a need to enhance the role of civil and self-regulated organisations in the SPPhS system nowadays. It will make relations between the parties of SPPhS effective, and this will solve all issues on SP between a $\mathrm{PhS}$, an employer and the executive authority in the optimal way. Settlement of conflicts between a PhS, an employer and the executive authority requires assigning of an authorized person who is responsible for social issues (APSI) at the labour collective of pharmaceutical institutions of all types of ownership and determining qualification requirements for the staffing.

4. The studies conducted have shown that there is a need to reconsider the current LP system in the pharmaceutical industry of Ukraine and to reform the LP system for pharmaceutical wholesale and retail branch.

\section{REFERENCES}

1. Конституція України // Офіиійний вісник України. - 2010. - №72/1. - 2598 c.

2. Толочко В.М., Зарічкова М.В. // Укр. вісник психоневрол. - 2013. - Т. 21, вип. 2 (75). - С. 136-137. 
3. Толочко В.М., Зарічкова М.В. // Вісник фармації. - 2012. - №2. - C. 37-39.

4. Толочко В.М., Зарічкова М.В. Інформ. лист. - Х.: Вид-во НФаУ, 2013. - 3 с.

5. Bazeley P. // Res. in the schools. - 2006. - Vol. 13, №1. - P. 64-74. [Електронний ресурс]. - Режим доступу до журн.: http://www.msera.org/Rits_131/Bazeley_131.pdf.

6. Chiang H., Goes P., Stohr E. // ACM Transaction on management information systems. - 2012. - Vol. 3 , №3. - P. 12-25. [Електронний ресурс]. - Режим доступу до журн.: http://www.informationintelligence.org/ Articles/Business_Intelligence_and_Analytics_Education_ACM_Oct_2012.pdf.

7. Driscoll L., Appiah-Yeboah A., Salib P., Rupert D. // Ecol. and Environmental Anthropol. - 2007. - Vol. 3, №1. - P. 19-28. [Електронний ресурс]. - Режим доступу до журн.: http://digitalcommons.unl.edu/cgi/ viewcontent.cgi? article $=1012 \&$ context $=i c w d m e e a$

8. European social Policy Forum. Brussels, 24-26 June. 1998. Summary report / Ed. by M.Carley. - №29, 28, 88.

9. Imai K., King G., Lau O. // J. of computational and graphical statistics. - 2008. - Vol. 17, №4. - P. 1-22. - DOI:10.1198/106186008X384898. - [Електронний ресурс]. - Режим доступу до журн.: http://gking. harvard.edu/files/z.pdf.

10. Tolochko V., Zarichkova M., Medvedyeva Y., Tolochko K. // Intern. J. of Pharmac. Sci. Review and Res. - 2013. - Vol. 18, Issue 1, January-February. [Електронний ресурс]. - Pежсим достуny: http://www.globalresearchonline.net/pharmajournal/voll8iss1.aspx.

11. Wickham H. // J. of statistical software. - 2011. - Vol. 40, №1. - P. 1-29. [Електронний ресурс]. - Режим доступу до журн.: http://www.jstatsoft.org/v40/i01/paper.

\begin{abstract}
АНАЛІЗ СТАВЛЕННЯ СПЕЦІАЛІСТІВ ФАРМАЦІЇ ДО ІСНУЮЧОЇ СИСТЕМИ СОЦІАЛЬНОГО ЗАХИСТУ ТА НАПРЯМКИ ІІІ РЕФОРМУВАННЯ

М.В.Зарічкова

Ключові слова: соціальний захист спеціалістів фрармації; соціальні послуги;

фармацевтична галузь; уповноважена особа з соціальних питань; охорона праці;

комп'ютерна програма ADPQ_(SPPhS)

Проаналізований соціальний статус спеціалістів фрармації (СФ) оптово-роздрібної ланки фрармацевтичної галузі України та їх ставлення до існуючої системи соціального захисту (C3). Досліджені можливості СФ щодо отримання соціальної допомоги за місцем роботи, участі у соціальних програмах та пропозицій до реформування існуючої системи СЗ. Встановлено необхідність підвищення ролі громадських та самоврядних організацій в системі соціального захисту спеціалістів фрармації (СЗСФ), що дозволить покращити відносини між учасниками СЗСФ та дієво впливати на вирішення конфліктних ситуацій між СФ та роботодавцем. Для цього запропоновано введення в трудовий колектив фрармацевтичних закладів усіх фрорм власності уповноваженої особи з соціальних питань. Уперше розроблена комп'ютерна програма ADPQ_(SPPhS) (Automatic data processing questionnaires (attitude to an existing social protection for pharmacy specialists (SPPhS)) для обробки результатів дослідження СЗСФ оптовороздрібної ланки фрармацевтичної галузі України.
\end{abstract}

\title{
АНАЛИЗ ОТНОШЕНИЯ СПЕЦИАЛИСТОВ ФАРМАЦИИ К СУЩЕСТВУЮЩЕЙ СИСТЕМЕ СОЦИАЛЬНОЙ ЗАЩИТЫ И ПУТИ ЕЕ РЕФОРМИРОВАНИЯ \\ М.В.Заричкова \\ Ключевые слова: социальная защита специалистов фрармации; социальные услуги;
} фрармацевтическая отрасль; уполномоченное лицо по социальным вопросам; охрана труда; компьютерная программа $A D P Q \_(S P P h S)$

Проанализирован социальный статус специалистов фармации (СФ) оптово-розничного звена фрармацевтической отрасли Украины и их отношение к существующей системе социальной защиты (СЗ). Исследованы возможности СФ относительно получения социальной помощи по месту работы, участия в социальных программах и предложений к реформированию существующей системы СЗ. Установлена необходимость повышения роли общественных и организаций самоуправления в системе социальной защиты специалистов фрармации (СЗСФ), что позволит улучшить отношения между участниками СЗСФ и действенно влиять на решение конфликтных ситуаций между СФ и работодателем. Для этого предложено введение в трудовой коллектив фрармацевтических учреждений всех форм собственности уполномоченного лица по социальным вопросам. Впервые разработана компьютерная программа ADPQ_(SPPhS) (Automatic data processing questionnaires (attitude to an existing social protection for pharmacy specialists (SPPhS)) для обработки результатов исследования СЗСФ оптово-розничного звена фрармацевтической отрасли Украины. 